DOI: https://doi.org/10.15407/techned2018.05 $: 061$

\title{
CURRENT AND VOLTAGE STATOR LIMITATION IN THREE-ZONE SPEED CONTROL SYSTEM OF MOTOR WITH PERMANENT MAGNETS USING OPTIMAL CONTROL STRATEGIES
}

$\quad$ Journal
Publisher
ISSN
Issue
Pages

\author{
Tekhnichna elektrodynamika \\ Institute of Electrodynamics National Academy of Science of Ukraine \\ 1607-7970 (print), 2218-1903 (online) \\ No 5, 2018 (September/October) \\ $61-64$
}

\section{Authors}

\section{O.I. Tolochko*, V.S. Bovkunovych ${ }^{* *}$, O.O. Burmelov}

National Technical University of Ukraine "Igor Sikorsky Kyiv Polytechnic Institute", pr. Peremohy, 37, Kyiv, 03056, Ukraine, e-mail: tolochko.ola@gmail.com

* ORCID ID : http://orcid.org/0000-0002-6871-0653

** ORCID ID : http://orcid.org/0000-0003-3160-3501

The method of limiting stator current and voltage in a three-zone speed control system using the optimal control strategies "Maximum torque per ampere" and "Maximum torque per volt" without using additional circuits for interior permanent magnet synchronous machine is proposed. The idea is to consistently include two dynamic-limiting blocks in the torque-forming component of the stator current, the first of which prevents the maximum permissible value of the stator current amplitude from exceeding, and the second one - the amplitude of the stator voltage. Formulas are derived for calculating the levels of the constraint without taking into account and taking into account the voltage drop of the stator at the active resistances. References 6 , figures 3. 
Key words: electrical drive, synchronous motor, permanent magnets, three-zone speed control, optimal control, maximum torque per ampere, maximum torque per volt, stator current and voltage amplitude limitations.

Received: 02.03 .2018

Accepted: 10.04 .2018

Published: 16.08 .2018

\section{References}

1. Schröder D. Elektrische Antriebe - Regelung von Antriebssystemen. Berlin, Heidelberg: Springer, 2009. $1336 \mathrm{p}$.

2. Bae B., Patel N., Schulz S., Sul S. New field weakening technique for high saliency interior permanent magnet motor. Conference Record of the Industry Applications Conference, $38^{\text {th }}$ IAS Annual Meeting

. October 2003. Vol. 2. Pp. 898-905.

3. Morimoto S., Sanada M., Takeda Y. Wide speed operation of interior permanent magnet synchronous motors with high performance current regulator. IEEE Trans. on Industry Applications 1994. Vol. 30. No 4. Pp. 920-926.

DOI:

https://doi.org/10.1109/28.297908

4. Lee J.H., Lee, J.H. Field-weakening strategy in condition of DC-link voltage variation using on electric vehicle of IPMSM. 2011 International Conference on Electrical Machines and Systems CEMS.2011.6073676

(ICEMS). 2011. Pp. 1-6. DOI: https://doi.org/10.1109/l

5. Babayomi O., Balogun A., Osheku C. Loss minimizing control of PMSM for electric power steering. 17 th UKSIM-AMSS International Conference on Modelling and Simulation. 2015. Pp. 438-443. DOI: 
https://doi.org/10.1109/UKSim.2015.80

6. Sue S.M., Pan C.T. Voltage-constraint-tracking-based field-weakening control of IPM synchronous motor drives. IEEE Transactions on Industrial Electronics. January, 2008. Vol. 55. No 1. Pp. 340-347.

PDF 